\title{
Less than 75 Percent of the Time
}

National Cancer Institute

\section{Source}

National Cancer Institute. Less than 75 Percent of the Time. NCI Thesaurus. Code C157472.

An indication that an individual did something, or something occurred, less than 75 percent of the time. 